\title{
Active-Transient Liquid Phase (A-TLP) Bonding of High Volume Fraction SiC Particle Reinforced A356 Matrix Composite
}

\author{
Guifeng Zhang*1, Bo Chen*2, Minzheng Jin*3 and Jianxun Zhang \\ State Key Laboratory for Mechanical Behaviour of Materials, Xi'an Jiaotong University, Xi'an 710049, China
}

The microstructure and shear strength of active-transient liquid phase (A-TLP) bonded joints of high volume fraction (70 vol\%) SiC particle reinforced A356 composite using an active interlayer of quaternary Al-33Cu-6Mg-1Ti (mass\%) were compared with TLP bonded joints using Ti-free Al-33Cu-6Mg interlayer to establish suitable interlayer composition design route. For the developed Ti-containing active filler metal, void free dense interface between $\mathrm{SiC}$ particle and bond seam with C-Al-Si(-Mg) or C-Al-Si-Ti product was readily obtained, and the joint shear strength increased with increasing joining temperature from $550^{\circ} \mathrm{C}$ to $580^{\circ} \mathrm{C}$ and $600^{\circ} \mathrm{C}$. While for the Ti-free interlayer, gaps between most $\mathrm{SiC}$ and metallic bond seam and between some matrix/bond interfaces remained, even at $600^{\circ} \mathrm{C}$. The maximum shear strength of the joints using Al-33Cu-6Mg-1 Ti and Al-33Cu-6Mg were $62 \mathrm{MPa}$ (with small fracture unit and partial fracture path within $\mathrm{A} 356$ matrix) at $600^{\circ} \mathrm{C}$ and $31 \mathrm{MPa}$ (with too large fracture unit and initial interface fracture path) at $580^{\circ} \mathrm{C}$, respectively. Thus, the beneficial effects of Ti addition into interlayer on improving (i) wettability between SiC particle and metallic bond seam and (ii) joint shear strength were demonstrated. [doi:10.2320/matertrans.M2014295]

(Received August 21, 2014; Accepted November 21, 2014; Published January 25, 2015)

Keywords: high volume fraction, aluminium matrix composite, interlayer composition design, transient liquid phase bonding

\section{Introduction}

High volume fraction (more than 50 vol\%) ceramic particle reinforced aluminium metal matrix composites (Al-MMCs) possess some attractive properties, such as low coefficient of thermal expansion, high wear resistance and high elastic modulus, thus they are extensively used in electronic packaging and aircraft fabrication. For fusion welding processes, compared with $\mathrm{Al}_{2} \mathrm{O}_{3}$ reinforced Al-MMCs, SiC reinforced Al-MMCs show poorer weldability due to the detrimental reaction between $\mathrm{SiC}$ and superheated liquid $\mathrm{Al}$, leading to weak, deliquescent and flake-like $\mathrm{Al}_{4} \mathrm{C}_{3}$ and micro cracks around $\mathrm{SiC}$ particle. ${ }^{1)}$ For brazing and transient liquid phase (TLP) bonding, the bond interface mainly falls into two groups, namely ceramic particle/metal $(\mathrm{P} / \mathrm{M})$ and matrix/ metal $(\mathrm{M} / \mathrm{M})$. Although TLP bonding using an interlayer containing sufficient melting point depressant (MPD, eutectic former for Al matrix) is able to remove oxide film via undermining mechanism ${ }^{2,3}$ ) and to obtain solid solution bond seam after isothermal solidification, the presence of numerous $\mathrm{P} / \mathrm{M}$ interface and lower joining temperature significantly deteriorates the wettability at joint interface, especially for high volume fraction ceramic particle reinforced AlMMCs.

The first factor determining the wettability should be the composition design route for braze or interlayer. The published braze or interlayer can be classified into four groups: (i) pure MPD, such as $\mathrm{Cu}, \mathrm{Ag}$ and $\mathrm{Ni}^{4-6)}$ In these cases, oxide film on Al matrix was removed well, but the typical defects of poor wettability at $\mathrm{P} / \mathrm{M}$ interface and particle segregation at bond center (for thick $\mathrm{Cu}$ and $\mathrm{Ag}$ ) damage joint strength. For Ni interlayer, Askew et al. stated that it can counteract particle segregation owing to the high

\footnotetext{
${ }^{* 1}$ Corresponding author, E-mail: gfzhang@mail.xjtu.edu.cn

${ }^{* 2}$ Graduate Student, Xi' an Jiaotong University

${ }^{* 3}$ Graduate Student, Xi' an Jiaotong University. Present address: FAW-

Volkswagen Co. Ltd., Chengdu City, China
}

Al-Ni eutectic temperature, but the bonding temperature of $655^{\circ} \mathrm{C}$ is too high. ${ }^{6}$ (ii) $\mathrm{Zn}$-based solder (e.g. $\mathrm{Zn}-4 \mathrm{Al}-3 \mathrm{Cu}$, mass \%). ${ }^{7,8)}$ For soldering $55 \mathrm{vol} \% \quad \mathrm{SiC}_{\mathrm{p}} / \mathrm{A} 356$ Al-MMC, ultrasonic vibration must be introduced two times to remove tenacious oxide film from A356 matrix surface at $420^{\circ} \mathrm{C}$ and further to enable $\mathrm{SiC}$ to shift into the molten solder at soldering temperatures of $420 \sim 500^{\circ} \mathrm{C}$. ${ }^{8}$ (iii) Al-based brazing filler metal including Al-12Si, Al-12Si-1.5Mg, ${ }^{9,10}$ $\mathrm{Al}-24 \mathrm{Cu}-5 \mathrm{Si}-1.5 \mathrm{Mg}^{11)}$ and $\mathrm{Al}-28 \mathrm{Cu}-5 \mathrm{Si}-2 \mathrm{Mg}$. ${ }^{12}$ ) Suzumura early demonstrated that $\mathrm{Al}-12 \mathrm{Si}-1.5 \mathrm{Mg}$ braze could spread on the substrate surface of Al matrix composite reinforced by short alumina fiber while Al-12Si remained the original shape of wire in wettability test at $620^{\circ} \mathrm{C}$ in vacuum. ${ }^{10)}$ However, the most popularly used Al-Si-Mg system is not suitable for A356 matrix due to its high melting range of $567 \sim 577^{\circ} \mathrm{C} .{ }^{10}$ ) For $\mathrm{Al}-24 \mathrm{Cu}-5 \mathrm{Si}-1.5 \mathrm{Mg}$ system braze with a relative low melting range, Niu et al. reported that voids were present at the $\mathrm{P} / \mathrm{M}$ interface in the joint of $55 \mathrm{vol} \% \mathrm{SiC}_{\mathrm{p}} / \mathrm{A} 356$ brazed at $550^{\circ} \mathrm{C}$ due to the poor wettability. ${ }^{11)}$ Zou et al. reported that with the aid of flux, $\mathrm{Al}-28 \mathrm{Cu}-5 \mathrm{Si}-2 \mathrm{Mg}$ braze could spread on 15 vol\% $\mathrm{SiC}_{\mathrm{p}} / 6061$ substrate, but could not spread on 30 vol\% $\mathrm{SiC}_{\mathrm{p}} / 6061$ composite, showing ball-like shape. ${ }^{12)}$ And (iv) Ni coating. By preparing Ni coating on $55 \mathrm{vol} \%$ $\mathrm{SiC}_{\mathrm{p}} / \mathrm{A} 356$, Lu et al. improved the wettability when soldering the composite and Fe-Ni-Co alloy (Kovar 4J29) with $\mathrm{Zn38-Cd58-Ag2-Cu2}$ solder. $^{13)}$

A number of previous reports have showed that high volume fraction ceramic reinforcement significantly deteriorates the wettability at $\mathrm{P} / \mathrm{M}$ interface. ${ }^{9-12)}$ So, the currently existing Al-based braze composition design route should be further improved. Weng and Chuang firstly added Ti into Snbased solder for joining $\mathrm{Al}_{2} \mathrm{O}_{3 \mathrm{p}} / 6061 \mathrm{Al}$, and they stated that $\mathrm{Sn} 10 \mathrm{Ag} 4 \mathrm{Ti}$ filler metal begins to adhere to the $\mathrm{Al}_{2} \mathrm{O}_{3}$ particulate aligned along the joining surface above $600^{\circ} \mathrm{C} .{ }^{14)}$ However, joint strength would be limited by the small solubility for Sn-Al system, and the microstructure showing the improvement on wettability by adding $\mathrm{Ti}$ was not provided. Huang et al. reported that although using $\mathrm{Ti}$ 
powder-containing Al-Si-SiC-Ti mixture as interlayer could improve the consistency of bond seam when reactive diffusion bonding 15 vol\% $\mathrm{SiC}_{\mathrm{p}} / 6063$ at $595^{\circ} \mathrm{C}$ for $90 \mathrm{~min}$, the joint shear strength was increased only by $5 \mathrm{MPa}$ compared with the case using Ti-free Al-Si mixed powders as interlayer. ${ }^{15)}$ The present authors attempted to add active element $\mathrm{Ti}$ into $\mathrm{Cu}$ and $\mathrm{Al}-12 \mathrm{Si}$ to improve the wettability at $\mathrm{P} / \mathrm{M}$ interface, ${ }^{16,17)}$ and called the TLP bonding process using an interlayer containing such active element, which is able to react with ceramic reinforcement, ${ }^{18)}$ active TLP (A-TLP) bonding. The combination between active interlayer and matrix, volume fraction of ceramic reinforcement and bonding parameters (temperature, pressure and time) significantly influence the success of A-TLP bonding of AlMMCs. ${ }^{16,17)}$

For high volume fraction $\mathrm{SiC}$ particle reinforced A356 matrix composite (70 vol\% $\left.\mathrm{SiC}_{\mathrm{p}} / \mathrm{A} 356\right)$, our previous experiments showed that the composite exhibited extremely poor TLP bondability when using popular $\mathrm{Cu}$ foil interlayer because the formed liquid phase was completely squeezed out of the interface, even at the microarea consisting of only A356 matrix, wetting was not achieved. Even for the novel $\mathrm{Al}-\mathrm{Cu}-\mathrm{Ti}$ interlayer containing active element (Ti) for $\mathrm{SiC}$ particle, which was developed and successfully used by us for $10 \mathrm{vol} \% \mathrm{SiC}_{\mathrm{p}} / \mathrm{A} 356$, the same poor wetting result as $\mathrm{Cu}$ foil interlayer was observed. These results, for the first time, showed that high volume fraction $\mathrm{SiC}$ particles significantly deteriorate the wettability not only at $\mathrm{P} / \mathrm{M}$ interfaces, but also at $\mathrm{M} / \mathrm{M}$ interfaces. The present study aims to design a new Ti-containing active filler metal with a medium melting range for A356 matrix and to improve the wettability at numerous $\mathrm{P} / \mathrm{M}$ interface for high volume fraction $\mathrm{SiC}$ reinforced $\mathrm{Al}-$ MMC by further optimizing bonding temperature.

\section{Experimental Procedure}

A 70 vol\% $\mathrm{SiC}_{\mathrm{p}} / \mathrm{A} 356 \mathrm{Al}-\mathrm{MMC}$, produced by vacuum infiltration of molten matrix into a pre-sintered bulk, was used as parent material. The $\mathrm{SiC}$ particles in the composite were of three different sizes, namely $10 \sim 15 \mu \mathrm{m}, 30 \sim 50 \mu \mathrm{m}$ and $90 \sim 150 \mu \mathrm{m}$. Trace amount of $\mathrm{Ti}$ and $\mathrm{Fe}$ was found in the matrix. The composite was cut into different dimensions of $7.5 \mathrm{~mm} \times 7.5 \mathrm{~mm} \times 3 \mathrm{~mm}$ and $15 \mathrm{~mm} \times 15 \mathrm{~mm} \times 3 \mathrm{~mm}$, used as top and bottom pieces in lap configuration.

An $80 \mu \mathrm{m}$ thick quaternary $\mathrm{Al}-33 \mathrm{Cu}-6 \mathrm{Mg}-1 \mathrm{Ti}$ (mass\%) active braze foil was developed by melting $\mathrm{Al}, \mathrm{Cu}, \mathrm{Mg}$ and Al-5Ti master alloy ingots in a crucible, followed by rapid solidification using a rotating $\mathrm{Cu}$ wheel. In this active foil, $\mathrm{Cu}$ was added as MPD, Mg as MPD and active element for $\mathrm{Al}$ matrix and $\mathrm{Ti}$ as active element for $\mathrm{SiC}$ particles. The TLP bonding process for Al-MMCs using Al-33Cu-6Mg-1Ti should be regarded as A-TLP bonding. ${ }^{16)}$ For comparison, a Ti-free $\mathrm{Al}-33 \mathrm{Cu}-6 \mathrm{Mg}$ (mass\%, near ternary eutectic) braze foil was produced by the same method. The melting ranges of Al-33Cu-6Mg-1Ti and Al-33Cu-6Mg brazing filler metal were measured by differential scanning calorimetry (DSC) analysis.

Prior to bonding, the parent Al-MMC pieces were polished using 600 grit diamond abrasive disk and then ultrasonically cleaned in alcohol. TLP bonding was carried out at 550, 560,

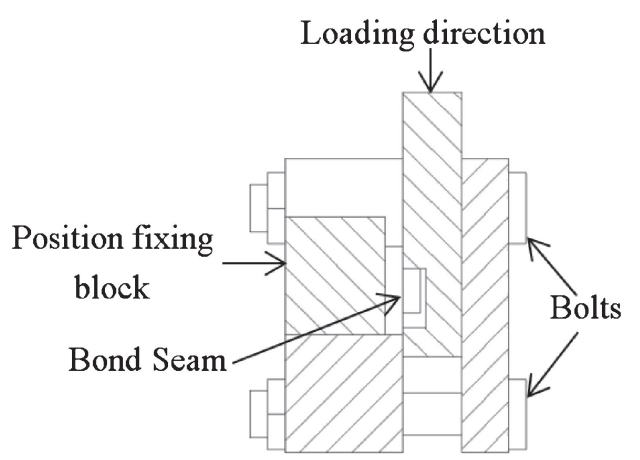

Fig. 1 Schematic of the shear test device.

580 and $600( \pm 5){ }^{\circ} \mathrm{C}$ for $30 \mathrm{~min}$ under $0.5 \mathrm{MPa}$ pressure in flowing $\mathrm{Ar}$ of $5 \mathrm{~L} / \mathrm{min}$. Specimens for microstructure examination were mechanically grinded and polished to reveal the cross-section using diamond abrasive disks. Backscattered electron (BSE) imaging and Energy dispersive x-ray spectroscopy (EDS) were used to investigate the microstructure and composition of the bond seam and fracture surface. The joints were evaluated by shear test using a device, as shown in Fig. 1, and under a loading speed of $0.5 \mathrm{~mm} / \mathrm{min}$.

By comparing joint shear strength, fracture surface, fracture path and interface microstructure for the two kinds of interlayer, the proposal of adding Ti as active element for $\mathrm{SiC}$ particle was demonstrated to be feasible in improving wettability at $\mathrm{P} / \mathrm{M}$ interfaces, especially for such high volume fraction $\mathrm{SiC}$ reinforced Al-MMC.

\section{Results and Discussion}

\subsection{Microstructure of the joints}

Figure 2 shows the DSC-temperature graph of the brazing filler metals. The melting ranges of the Al-33Cu-6Mg-1Ti and $\mathrm{Al}-33 \mathrm{Cu}-6 \mathrm{Mg}$ were $504 \sim 518^{\circ} \mathrm{C}$ and $503 \sim 515^{\circ} \mathrm{C}$, respectively, showing that small addition of Ti did not result in significant increase in melting range. Since the melting ranges were below the solidus of the A356 metal matrix $\left(557^{\circ} \mathrm{C}\right)$, they can be an option as braze or interlayer.

Figure 3 shows the variation of joint microstructure with bonding temperature using $\mathrm{Al}-33 \mathrm{Cu}-6 \mathrm{Mg}-1 \mathrm{Ti}$ brazing filler metal. At $560^{\circ} \mathrm{C}$, the interfacial gap between the bond seam and the parent Al-MMC, especially at $\mathrm{P} / \mathrm{M}$ interface, can be observed due to poor wettability. With increasing bonding temperature, the interfacial gap tended to disappear, and the width of the bond seam decreased from about $20 \mu \mathrm{m}$ at $560^{\circ} \mathrm{C}$ to less than $10 \mu \mathrm{m}(2 \mu \mathrm{m}$ between some large $\mathrm{SiC}$ particles) at $600^{\circ} \mathrm{C}$, but no particle segregation was observed. Especially at $600^{\circ} \mathrm{C}$, an $\sim 2 \mu \mathrm{m}$ thick transition layer was formed at the $\mathrm{P} / \mathrm{M}$ interface. The EDS point analysis results (in Fig. 3(f)) showed that the transition layer was composed of $\mathrm{C}-\mathrm{Al}-\mathrm{Si}$ with trace amount of $\mathrm{Mg}$ in the level of $0.2 \sim 0.4$ at $\%$, as shown in the Table 1 , but $\mathrm{Ti}$ was not detected in this case.

In contrast, for $\mathrm{Al}-33 \mathrm{Cu}-6 \mathrm{Mg}$ interlayer, the microstructure showed in Fig. 4 demonstrated that the absence of active element Ti had negative effects on the oxide film removal and wetting of $\mathrm{SiC}$ particles. Even at $600^{\circ} \mathrm{C}$, there were still 

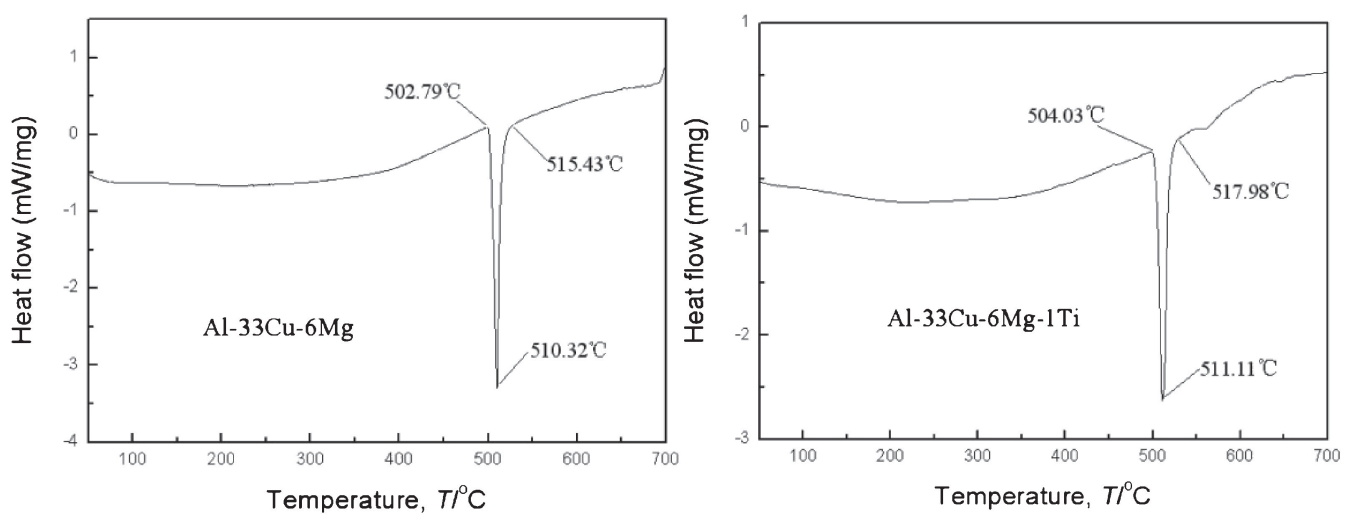

Fig. 2 Melting ranges of $\mathrm{Al}-33 \mathrm{Cu}-6 \mathrm{Mg}-1 \mathrm{Ti}$ and $\mathrm{Al}-33 \mathrm{Cu}-6 \mathrm{Mg}$ brazes.
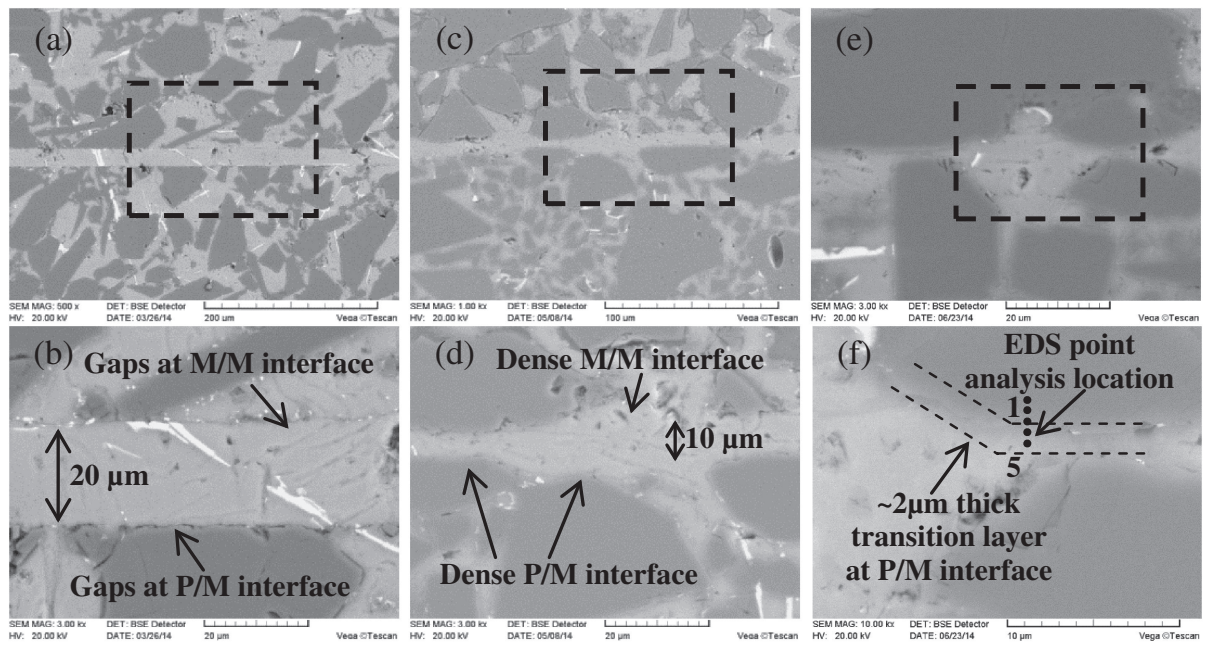

Fig. 3 Interface microstructure of joints using $\mathrm{Al}-33 \mathrm{Cu}-6 \mathrm{Mg}-1 \mathrm{Ti}$ brazing filler metal as a function of temperatures: (a), (b) at $560^{\circ} \mathrm{C}$; (c), (d) at $580^{\circ} \mathrm{C}$; (e), (f) at $600^{\circ} \mathrm{C}$.
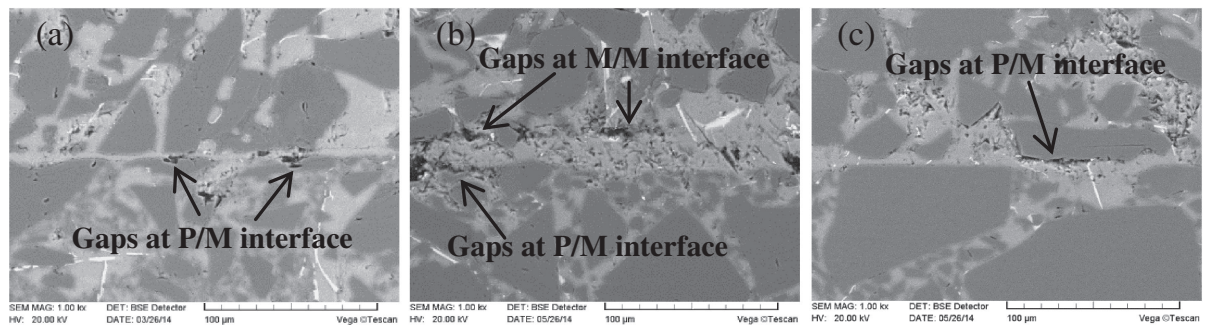

Fig. 4 Microstructure of joints using Al-33Cu-6Mg brazing filler metal, (a) at $560^{\circ} \mathrm{C}$; (b) at $580^{\circ} \mathrm{C}$; (c) at $600^{\circ} \mathrm{C}$.

Table 1 EDS point analysis results of location in Fig. 3(f), at\%.

\begin{tabular}{ccrcc}
\hline Point & $\mathrm{C}$ & $\mathrm{Al}$ & $\mathrm{Si}$ & $\mathrm{Cu}$ \\
\hline 1 & 35.4 & 8.1 & 56.5 & \\
$2^{*}$ & 26.9 & 25.1 & 47.7 & \\
3 & 17.5 & 52.3 & 29.8 & 0.4 \\
4 & 10.9 & 66.8 & 21.8 & 0.6 \\
5 & 17.0 & 66.1 & 16.4 & 0.5 \\
\hline
\end{tabular}

*Additional Mg $0.2 \%$.

microvoid at some $\mathrm{M} / \mathrm{M}$ interfaces and gaps at some $\mathrm{P} / \mathrm{M}$ interfaces (indicated by the arrows in Fig. 4) due to poor wettability. Moreover, no obvious transition layer was observed at the $\mathrm{P} / \mathrm{M}$ interface. Also, no particle segregation was observed.
Comparing the microstructures, the densification at both $\mathrm{M} / \mathrm{M}$ and $\mathrm{P} / \mathrm{M}$ interface were improved by using Ticontaining brazing filler metal at $580^{\circ} \mathrm{C}$ and $600^{\circ} \mathrm{C}$. So it is believed that $\mathrm{Ti}$ addition could contribute to removing oxide film at $\mathrm{M} / \mathrm{M}$ interface and improving wettability at $\mathrm{P} / \mathrm{M}$ interface. For $\mathrm{M} / \mathrm{M}$ interface, unlike monolithic metal, great numbers of fixed $\mathrm{SiC}$ particles with a network structure would restrict the free expansion of the matrix and then restrict the cracking of oxide film (resulting from the mismatch in coefficient of thermal expansion (CTE) between oxide film and matrix) during heating even to $600^{\circ} \mathrm{C}$, thus inhibiting the effect of MPDs of $\mathrm{Cu}$ and $\mathrm{Mg}$ on undermining oxide film. ${ }^{3,10)}$ In this case, the addition of $\mathrm{Ti}$ becomes essential because $\mathrm{Ti}$ is able to offer an chemical route to break continuous oxide film, inducing and enhancing undermining (indirect physical route, depending on mismatch in CTE) 
oxide film by MPD. ${ }^{17)}$ With the aid of Ti, as the bonding temperature increased over the solidus of the A356 matrix, the matrix could be partly melted, allowing oxide film fragment to flow away and resulting in mixing between molten interlayer and molten matrix with low superheat degree, and thus forming dense $\mathrm{M} / \mathrm{M}$ interface. For $\mathrm{P} / \mathrm{M}$ interface, higher temperature $\left(600^{\circ} \mathrm{C}\right)$ could activate the active element of liquid $\mathrm{Ti}$ as a catalyst, facilitating the formation of the C-Al-Si(- $\mathrm{Mg})$ transition layer at $\mathrm{P} / \mathrm{M}$ interface, where $\mathrm{Si}$ content decreased and $\mathrm{Al}$ content increased from $\mathrm{SiC}$ particle to the bond seam.

The manufacture process of the parent material should be responsible for the absence of particle segregation. Instead of loose $\mathrm{SiC}$ powder, a rigid $\mathrm{SiC}$ preform was used in the pressure infiltration process. The $\mathrm{SiC}$ particles in the preform were fixed. Thus they were not able to be pushed away by the liquid phase during isothermal solidification stage of the TLP bonding process. However, as a result of higher bonding temperature over solidus, several $0.5 \mathrm{~mm}$ diameter droplets were formed on the composite surface after joining.

\subsection{Shear strength}

Figure 5 shows the effect of interlayer composition on joint shear strength at different temperatures. For Al-33Cu$6 \mathrm{Mg}$, joint shear strengths were around $30 \mathrm{MPa}$ at each bonding temperature, and slightly decreased at $600^{\circ} \mathrm{C}$. The maximum shear strength was $31 \mathrm{MPa}$ at $580^{\circ} \mathrm{C}$. While for Al-33Cu-6Mg-1Ti, shear strength of the joints increased significantly with increasing temperature. The average shear strength at $600^{\circ} \mathrm{C}$ increased by $100 \%$ compared with that at $550^{\circ} \mathrm{C}(29 \mathrm{MPa})$, reaching $62 \mathrm{MPa}$. At each bonding temperature, $\mathrm{Al}-33 \mathrm{Cu}-6 \mathrm{Mg}-1 \mathrm{Ti}$ interlayer could produce higher joint shear strength comparing with $\mathrm{Al}-33 \mathrm{Cu}-6 \mathrm{Mg}$ interlayer. The result demonstrated that small addition of $\mathrm{Ti}$ could significantly improve shear strength (especially at higher

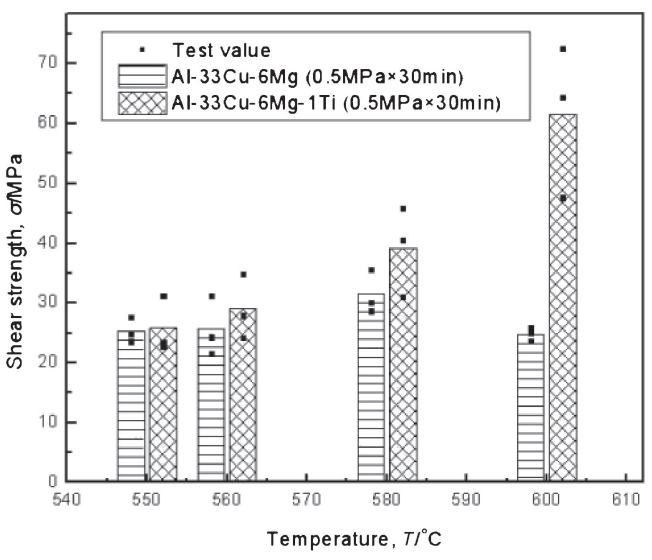

Fig. 5 Joint shear strengths for different interlayers with and without Ti at different temperatures.

temperature), while Mg was unable to improve shear strength even at higher temperature. This can be explained by the improvement on wettability at $\mathrm{M} / \mathrm{M}$ (at both $580^{\circ} \mathrm{C}$ and $600^{\circ} \mathrm{C}$ ) and $\mathrm{P} / \mathrm{M}$ (especially at $600^{\circ} \mathrm{C}$ ) interface (comparing Fig. 3(c), (e) with Fig. 4(b) and (c)). The densification of $\mathrm{P} / \mathrm{M}$ interface resulted from the reaction between $\mathrm{Ti}$ and $\mathrm{SiC}$ particles that could be demonstrated by the presence of small and scattered $\mathrm{Al}-\mathrm{Si}$-Ti phase adhered on $\mathrm{SiC}$ on joint fracture surface (see next section). Moreover, the presence of trace amount of $\mathrm{Mg}$ at the $\mathrm{P} / \mathrm{M}$ interface in the level of $0.2 \sim$ 0.4 at $\%$ could subsequently improve the wettability at $\mathrm{P} / \mathrm{M}$ interfaces.

\subsection{Fracture path and fracture surface}

Figure 6 and Figure 7 show the fracture paths of the joints using $\mathrm{Al}-33 \mathrm{Cu}-6 \mathrm{Mg}-1 \mathrm{Ti}$ and $\mathrm{Al}-33 \mathrm{Cu}-6 \mathrm{Mg}$, respectively. Joints with low and high shear strength exhibits two different fracture path propagation modes, as shown in Fig. 8. For low
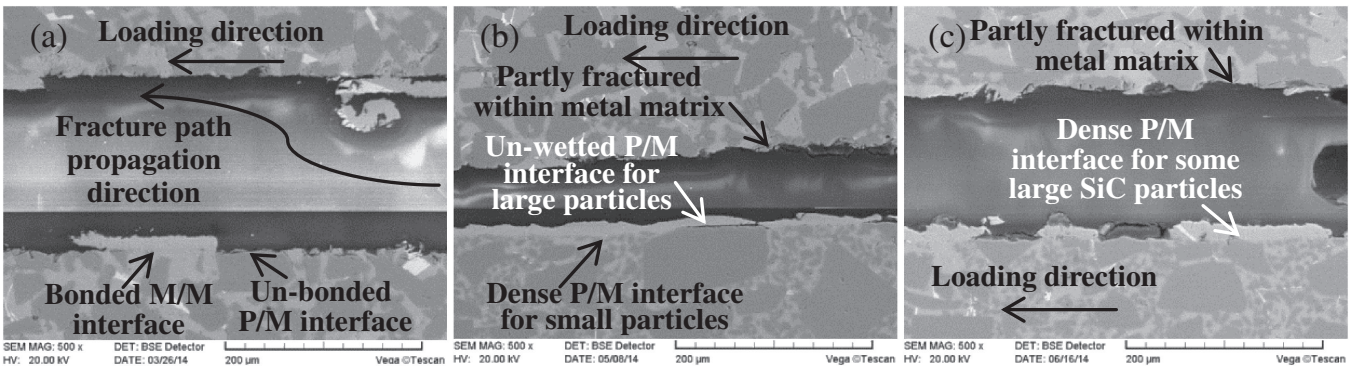

Fig. 6 Fracture path of joints using Al-33Cu-6Mg-1Ti brazing filler metal, (a) at $560{ }^{\circ} \mathrm{C}$; (b) at $580^{\circ} \mathrm{C}$; (c) at $600^{\circ} \mathrm{C}$.
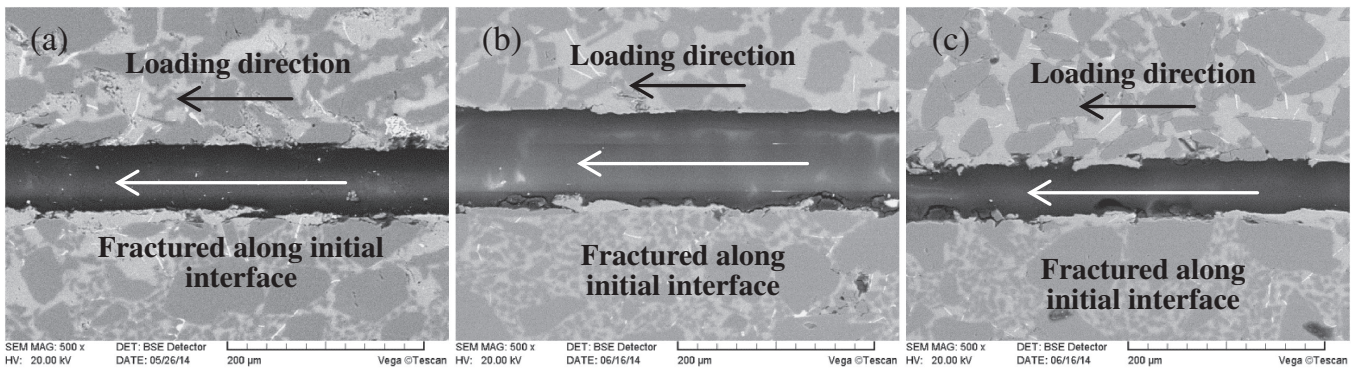

Fig. 7 Fracture path of joints using Al-33Cu-6Mg brazing filler metal, (a) at $560^{\circ} \mathrm{C}$; (b) at $580^{\circ} \mathrm{C}$; (c) at $600^{\circ} \mathrm{C}$. 

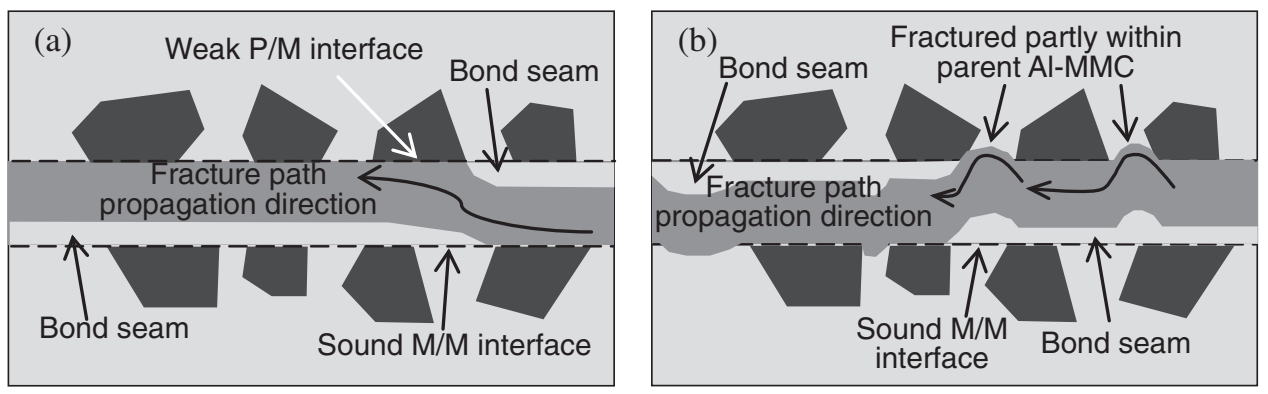

Fig. 8 Schematic of fracture path propagation modes: (a) fractured alternately along interfaces (for Al-Cu-Mg foil and Al-Cu-Mg-Ti only at $560^{\circ} \mathrm{C}$ ) and (b) fractured partly within the matrix of parent Al-MMC (for Al-Cu-Mg-Ti at 580 and $600^{\circ} \mathrm{C}$ ).
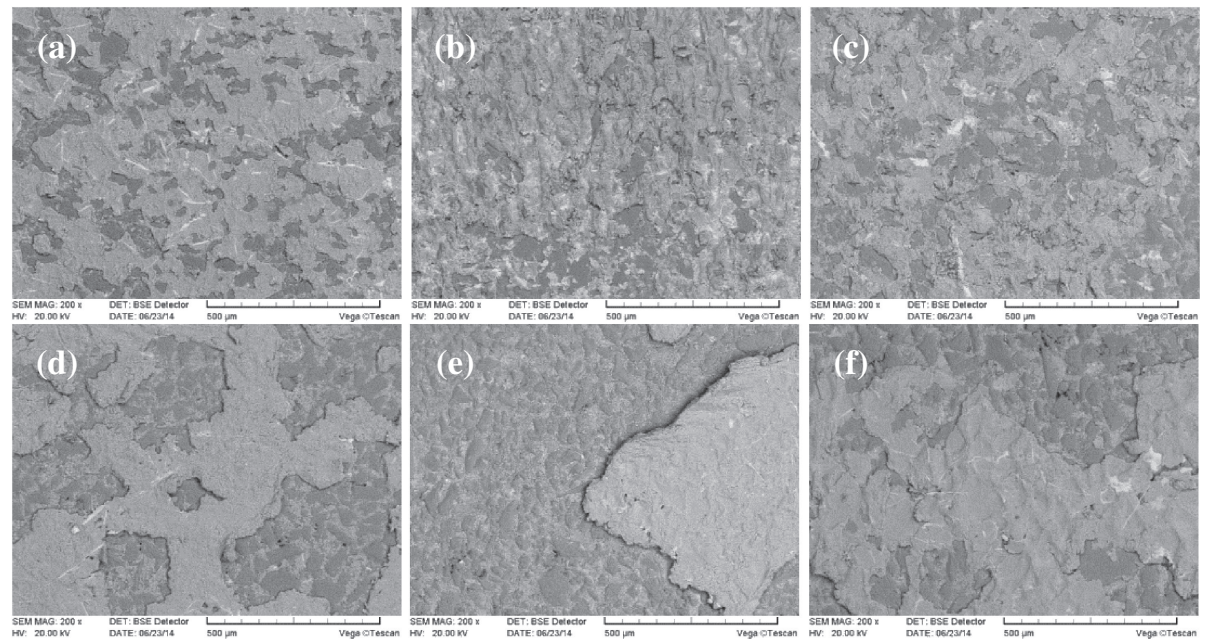

Fig. 9 Fracture surface of joints using $\mathrm{Al}-33 \mathrm{Cu}-6 \mathrm{Mg}-1 \mathrm{Ti}$ (a) at $560^{\circ} \mathrm{C}$, (b) at $580^{\circ} \mathrm{C}$ and (c) at $600^{\circ} \mathrm{C} ; \mathrm{Al}-33 \mathrm{Cu}-6 \mathrm{Mg}(\mathrm{d})$ at $560^{\circ} \mathrm{C}$, (e) at $580^{\circ} \mathrm{C}$ and (f) at $600^{\circ} \mathrm{C}$.

shear strength (around 30 MPa) joints produced using Al$33 \mathrm{Cu}-6 \mathrm{Mg}-1 \mathrm{Ti}$ at $560^{\circ} \mathrm{C}$ and $\mathrm{Al}-33 \mathrm{Cu}-6 \mathrm{Mg}$ at 560,580 and $600^{\circ} \mathrm{C}$, the fracture path was straightly along initial interface due to poor wettability at $\mathrm{M} / \mathrm{M}$ interface. While for high shear strength (above $40 \mathrm{MPa}$ ) joints produced using Al$33 \mathrm{Cu}-6 \mathrm{Mg}-1 \mathrm{Ti}$ at $580^{\circ} \mathrm{C}$ and $600^{\circ} \mathrm{C}$, the fracture path propagated into the metal matrix of the parent Al-MMC due to the sound $\mathrm{M} / \mathrm{M}$ interface, but the propagation direction changed to $\mathrm{P} / \mathrm{M}$ interface when the fracture path meet the $\mathrm{SiC}$ reinforcement within the composite. The results also demonstrated that (i) the added Ti could improve the wettability at $\mathrm{M} / \mathrm{M}$ interface significantly, (ii) the improvement in wettability at $\mathrm{P} / \mathrm{M}$ interface by adding $\mathrm{Ti}$ was preferentially achieved at the area with small $\mathrm{SiC}$ particles (Fig. 6(b) and (c)), and (iii) the improved bonding at $\mathrm{P} / \mathrm{M}$ interface was insufficient to contend against the bonding between $\mathrm{SiC}$ particles and matrix within ceramic preform.

Figure 9 shows the fracture surface of the joints using Ticontaining and Ti-free interlayers. For Ti-containing interlayer, the bond seam metal adhered on the parent Al-MMC was discontinuous with small size, and the areas with bare $\mathrm{SiC}$ particles was dispersed in small size, showing small fracture unit. While for Ti-free brazing filler metal, the bond seam metal adhered on the parent Al-MMC was continuous in large scale. The areas with bare $\mathrm{SiC}$ particles were large, indicating large fracture unit along $\mathrm{P} / \mathrm{M}$ interface due to poor wettability.
At some local areas on the fracture surface of joints produced using $\mathrm{Al}-33 \mathrm{Cu}-6 \mathrm{Mg}-1 \mathrm{Ti}$ at $580^{\circ} \mathrm{C}$ and $600^{\circ} \mathrm{C}$, Ticontaining particulate phases were found to be adhered on $\mathrm{SiC}$ particles, which was shown in Fig. 10. Although the adhered Ti-containing phase was small $(\sim 2 \mu \mathrm{m})$, the microstructure and shear strength has been significantly improved. It should be noted that the phases at position 2 and 4 contained large amount of $\mathrm{C}$ element and very small amount of Ti element, which can be considered to be the evidence of reactive wetting at partial region owing to the high affinity between $\mathrm{Ti}$ and $\mathrm{C}$. The other positions contained large amount of Ti but no $\mathrm{C}$ was detected, indicating that some $\mathrm{Ti}$ atoms could segregate onto the $\mathrm{SiC}$ particle surface. The segregation of Ti atoms should also be beneficial to wetting of $\mathrm{SiC}$ particle.

\section{Conclusions}

(1) For Ti-free $\mathrm{Al}-33 \mathrm{Cu}-6 \mathrm{Mg}$ interlayer, interfacial gap at both $\mathrm{M} / \mathrm{M}$ and $\mathrm{P} / \mathrm{M}$ interfaces could not be eliminated even at $600^{\circ} \mathrm{C}$, showing that too high volume fraction of $\mathrm{SiC}$ deteriorates the wettability not only at $\mathrm{P} / \mathrm{M}$ interface, but also at $\mathrm{M} / \mathrm{M}$ interface. The too low CTE of the composite restricted the cracking of oxide film by mismatch in CTE between oxide film and matrix, thus inhibiting the effect of MPDs of $\mathrm{Cu}$ and $\mathrm{Mg}$ on undermining oxide film at $\mathrm{M} / \mathrm{M}$ interface. 

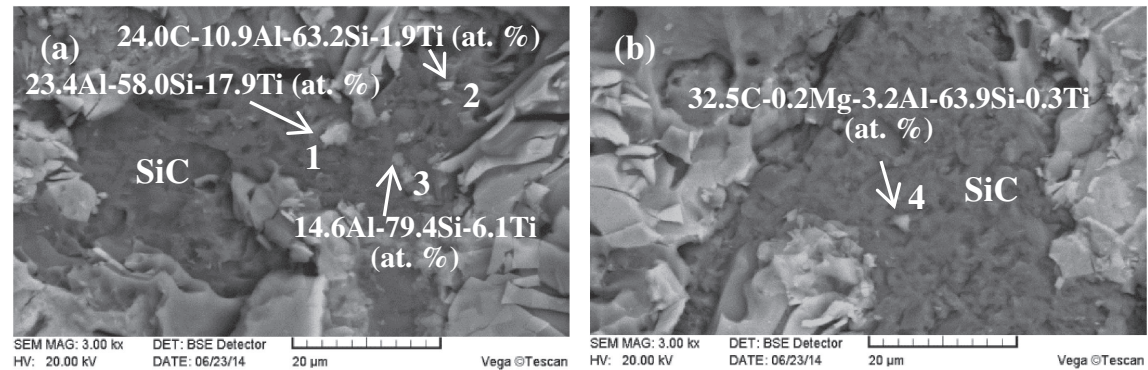

Fig. 10 Fracture surface of joints using $\mathrm{Al}-33 \mathrm{Cu}-6 \mathrm{Mg}-1 \mathrm{Ti}$ showing $\mathrm{Ti}$ containing phase adhered on $\mathrm{SiC}$ particles at (a) $580^{\circ} \mathrm{C}$ and (b) $600^{\circ} \mathrm{C}$.

(2) For Al-33Cu-6Mg-1Ti active interlayer, the interfacial gap at both $\mathrm{M} / \mathrm{M}$ and $\mathrm{P} / \mathrm{M}$ interfaces could be eliminated at 580 and $600^{\circ} \mathrm{C}$. The improvement of wettability at $\mathrm{P} / \mathrm{M}$ interface can be attributed to (i) formation of $\mathrm{a} \sim 2 \mu \mathrm{m}$ thick transition layer consisting of C-Al-Si with trace amount of $\mathrm{Mg}$, (ii) the presence of $\mathrm{C}-\mathrm{Al}-\mathrm{Si}-\mathrm{Ti}$ particulate reaction product containing $\mathrm{Ti}$ $(\sim 2 \mu \mathrm{m})$ on the surface of $\mathrm{SiC}$ particles, and (iii) segregation of $\mathrm{Ti}$ atoms on the surface of $\mathrm{SiC}$ particles.

(3) The active element $\mathrm{Ti}$ could significantly improve shear strength from $29 \mathrm{MPa}$ at $560^{\circ} \mathrm{C}$ to $62 \mathrm{MPa}$ at $600^{\circ} \mathrm{C}$. While the highest shear strength of joints produced using $\mathrm{Al}-33 \mathrm{Cu}-6 \mathrm{Mg}$ was only $31 \mathrm{MPa}$ at $580^{\circ} \mathrm{C}$.

(4) For the joints produced using Al-33Cu-6Mg-1Ti, the fracture could propagate partly into the matrix, showing small fracture unit $(50 \mu \mathrm{m})$ at the fracture surface, and Ti-containing phase adhered on $\mathrm{SiC}$ particles was found at 580 and $600^{\circ} \mathrm{C}$. While the joints produced using $\mathrm{Al}-33 \mathrm{Cu}-6 \mathrm{Mg}$ exhibited large fracture unit $(500 \mu \mathrm{m})$ along initial interface due to poor wettability.

(5) By comparing microstructure, shear strength, fracture surface and path, it was demonstrated that $\mathrm{Ti}$ addition can remarkably improve the wettability at both $\mathrm{M} / \mathrm{M}$ and $\mathrm{P} / \mathrm{M}$ interface, especially for such composite containing high volume fraction of $\mathrm{SiC}$.

\section{Acknowledgments}

The present research was supported by the National
Science Foundation of China (No. 51275390 and No. 50875199).

\section{REFERENCES}

1) A. Ureña, M. D. Escalera and L. Gil: Compos. Sci. Technol. 60 (2000) 613-622.

2) Z. Xu, J. Yan and S. Yang: Mater. Sci. Eng. A 415 (2006) 80-86.

3) W. F. Gale and D. A. Butts: Sci. Technol. Weld. Join. 9 (2004) 283300.

4) A. A. Shirzadi and E. R. Wallach: Mater. Sci. Technol. 13 (1997) 135142.

5) A. Suzumura and Y. Xing: Mater. Trans., JIM 37 (1996) 1109-1115.

6) J. R. Askew, J. F. Wilde and T. I. Khan: Mater. Sci. Technol. 14 (1998) 920-924.

7) J. C. Yan, H. B. Xu and L. Shi: Sci. Technol. Weld. Join. 13 (2008) 760-764.

8) Y. Zhang, J. Yan, X. Chen and Y. Cui: Trans. Nonferrous Met. Soc. 20 (2010) 746-750.

9) X. Zhang, G. Quan and W. Wei: Compos. Part A 30 (1999) 823-827.

10) A. Suzumura and Y. Xing: Preprints of the National Meeting of JWS 55 (1994) 282-283.

11) J. T. Niu, X. W. Luo, H. Tian and J. Brnic: Mater. Sci. Eng. B 177 (2012) 1707-1711.

12) J. Zou, R. Xu and Q. Zhao: Mater. Develop. Appl. 18 (2003) 5-8.

13) J. Lu, Y. Mu, X. Luo and J. Niu: Mater. Sci. Eng. B 177 (2012) 17591763.

14) W. P. Weng and T. H. Chuang: Mater. Manuf. Process. 12 (1997) 11071132.

15) J. H. Huang, Y. L. Dong and Y. Wan: J. Mater. Proc. Technol. 190 (2007) 312-316.

16) G. Zhang, J. Zhang and Y. Pei: Mater. Sci. Eng. A 488 (2008) 146-156.

17) G. Zhang, W. Su, J. Zhang and A. Suzumura: J. Mater. Eng. Perform. 22 (2013) 1982-1994.

18) R. Asthana: J. Mater. Sci. 33 (1998) 1959-1980. 